Kihoon Kim (김기훈)

\title{
Pietas in pro Sexto Roscio of Cicero and Confucian 孝 (xiao)
}

\section{The case of pro Sexto Roscio ${ }^{1}$}

Cicero's early speech pro Sexto Roscio is a well-known source in which a certain conception of Roman humanitas is contained. ${ }^{2}$ The case was about parricidium. In early 80 BCE, Cicero, a 26-year-old youngster at the time, took the case, and successfully defended Sextus Roscius the younger, who had been accused of killing his own father Sextus Roscius the elder, a rich Italian in the municipium of Ameria. Cicero won and Sextus Roscius was acquitted. This criminal case, however, also has political implications, because beside the prosecutor lurked an influential figure named L. Cornelius Chrysogonus. He had been a Greek slave under L. Cornelius Sulla, who had marched with his army into Rome and obtained hegemony in 82 BCE. At that time of the trial of Roscius, Chrysogonus was arguably a libertus of some, perhaps substantial, influence.

According to Cicero in this speech, Sextus Roscius the elder was killed in Rome some months after 1st June 81 BCE. This date seems to be the deadline of Sulla's tabula proscriptionis, up until which the proscription could have been valid. The death of Roscius the father was communicated to relatives sooner than to his immediate family. Following his death, he was proscribed. His possessions were auctioned, bought by Chrysogonus at a giveaway price, and some were brought to the Roscii. Thus, Roscius the son was disinherited before the funeral ceremony was over, and forced to take refuge in Rome, since he was targeted to be killed by the Roscii who felt themselves to be in danger after the decemviri's visit to Sulla's camp. Among this delegation from Ameria, through which the local leaders attempted to seek amnesty for Roscius the elder from Sulla, T. Roscius Capito was the chief member, but its request, a meeting with Sulla, was blocked by Chrysogonus. After Roscius the younger had escaped to Rome, the delegation members accused him of parricide, enforcing the lex Cornelia de sicariis et veneficis and employing Erucius as the prosecutor. Such is a sum-

1 This paper was originally presented at the International Conference "Confucius and Cicero: Old ideas for a New World - New Ideas for an Old World” 6th September, 2017 at Turin University, Italy. The author is sincerely grateful to the organizers of the conference, and to the audience members.

2 Cf. Ahn (2009); Storch (2006).

2 OpenAccess. () 2019 Kihoon Kim, published by De Gruyter. (cc) BY-NC-ND This work is licensed under the Creative Commons Attribution-NonCommercial-NoDerivatives 4.0 License. https://doi.org/10.1515/9783110616804-010 
mary of the circumstances in which Roscius was accused, based on Cicero's argument. ${ }^{3}$

The political reforms of the dictator Sulla seemed to have been accomplished and the Roman constitution normalized by the revival of regular lawsuits such as the Roscius case in the early 80s BCE. Nonetheless, there was probably no one who would take the case and defend him against the charge while the cruel traces of civil war and the terror of Sullan rule were still haunting the Roman people. Moreover, the situation might have been even more unfavorable to the accused since the prosecutor Erucius was believed to be supported by Chrysogonus and the Sullan party. Still a novice, and not yet holding any magistracy, Cicero took on the case, and by defending his client successfully rose to prominence as a brave patronus. This case is also well-known as his first causa publica. The main issue in pro Sexto Roscio is parricide, the ultimate crime of filial impiety. Although the other, no less important, aspect of this speech is Cicero's judgment about the political situation of the period described above, the focus of this paper will be limited mainly to part of the argumentatio, especially $\S \S 37-72$, in which the theme of pietas ${ }^{4}$ is more directly addressed.

\section{Reading pietas in pro Sexto Roscio}

The issue in the case on which Cicero concentrates, and the constitutio coniecturalis, is whether Roscius killed his father or not. This appears in the first part of the argumentatio. In $\S \S 35-36$ Cicero divides his speech and says that there are three things which obstruct the charged man, crimen adversariorum et audacia et potentia. Among these, his responsibility consists in rejecting the charge that the accuser Erucius has brought forward. On the other hand, to resist the other two, he says, is a matter for the Roman people to entrust to the jury, but this he will also deal with himself in the latter part of his speech (§§ 83-123; §§ 124-142), which is especially concerned with the political dimension of the case.

The word parricidium is used in the speech 9 times, and most examples occur in $\S \S 37-72$. Confronting the question of an parricidium commiserit, Cicero answers in the negative by arguing ex persona ( $(39)$, ex causa ( $\S \S 40-54)$ and ex facto ipso ( $\S \S 73-79)$. These strategic elements may have been a response to the argument by which Erucius would try to convince the jury. At the very beginning

3 Cf. $\S \S 15-29$, narratio of pro Sexto Roscio.

4 All the words which are concerned with pius or pietas, are in $\S \S 37-72$ : pietas (§ 37); pii (§ 66); impie, impiis (§ 67); impios (§ 69). 
of his argument, Cicero asks with assurance a rhetorical question about the wickedness of the charge:

$\S 37:$ Sextus Roscius stands accused of the murder of his father. Immortal gods, what an outrageously criminal act, the type of act that seems to comprise within it every crime that exists! The philosophers rightly point out that filial duty (pietas) can be violated by a mere look. What punishment, then, could be devised which would be severe enough for a man who had murdered his own parent - a person he was bound by every law, human and divine, to defend with his life if necessary? ${ }^{5}$

In the cited passage, the word pietas attracts attention. Though it is not the direct theme of the argument or of the speech, Cicero seems to consider the charge as referencing an impious crime. It is interesting that he prefers to emphasize or even exaggerate rather than to minimize the criminality of the charge itself. This attitude of Cicero's about parricide is shown consistently in the argument. According to him, parricide is a cruel, unnatural, even incredible crime. On this point, his choice of topos, the crime's inconceivability, is strategic and effective, ${ }^{6}$ because, as he will state more concretely in $\S \S 70-72$, parricide and the punishment for it were well-known not only to the jury, but also to the audience of Roman people.

Answering the question qui homo? (§ 39), Cicero tries to show that the character of Roscius is quite different from what the prosecutor would have claimed. In short, since Roscius has been removed from luxuria and cupiditas, and because his life has been characterized by duty, such a man could not have committed one of the cruelest crimes. Likewise, Cicero keeps insisting that there was no sufficient cause or motive for Roscius to kill his father. In other words, Roscius had neither any inner impietas, nor any abnormal external impetus urging him on. Whereas the prosecutor had claimed that Roscius was so deviant that he might dare to kill his father, the strategy of Cicero's argument, appealing to common sense, focused on the claim that such a heinous crime would have require sufficient motivation. Thus, Cicero assumes a dual refutation: on the one hand, the anomalous nature of parricide has to be emphasized; on the other, Roscius is portrayed as an ordinary, or indeed a rather pious son. In the course of this argument, the early perspective of Cicero and the Romans on filial piety appears to be reflected in a roundabout way.

5 All the English translations of pro Sexto Roscio in this paper are cited from Berry (2000). 6 Cf. Lentano (2015) 144. The theme of parricide in the declamatio might have had some educational role within Cicero's conception of filial piety. 
§63: For men’s tender feelings are strong, the ties of blood are powerful ones, and nature herself protests against suspicions of this kind. It is without doubt unnatural and monstrous that a being of human shape and form should so far surpass the wild animals in savagery as to have deprived of the light of day, in the most shocking way possible, the very people to whom he owes the fact that he too can enjoy this light. Even wild animals live at peace with each other, thanks to the ties of birth and upbringing, and thanks to nature herself.

Frequently, Cicero characterizes parricide as a crime against human nature. As in the cited passage, the words which he uses to describe parricide in the speech are mainly described as, e.g., extraordinary, ominous, and unnatural: parricide is nefarium ( $\S 37 ; 62 ; 65 \mathrm{ff}$. ), scelus/scelestum ( $\S 37 ; 64 ; 66 ; 67 \mathrm{ff}$.), novum (§§ 1; $44,82,124,126,153)$, portentum ( $\S \S 38,63$ ), prodigium ( $\$ 38)$, monstrum ( $(63)$. In short, parricide is an inhumane crime and so it is inconceivable that the nature of any human being could be the cause of such a crime, unless he or she were less than a wild animal. So, the very nature of anyone who severed the blood-relationship by committing parricide is monstrous and out of order, since the filial bond is based on the relationship between children and parents which even wild animals by nature recognize. Therefore, unless some unnatural cause intervenes, such a relationship should be unbreakable. On this point, pietas is a kind of or a part of humanitas or human nature, ${ }^{7}$ in contrast to immanitas (§ 63).

If the relationship could be called pietas, especially on the side of the children, it is interesting that, as seen in $\S 37$, Cicero also seems to suppose that pietas can be undermined quite easily and often (voltu saepe laeditur pietas). In other words, not only are human beings endowed by nature with pietas erga parentes, it is also something that deserves to be maintained. If pietas in its earlier form is part of the human condition based on biological causation and dependency, it later becomes filial 'duty', deriving from a continued relationship bound by every divine and human law ( $\S 37$ ). This social and legal dimension of pietas would appear to be related to patria potestas. The prosecutor Erucius might have pointed out that the son's violation of pietas incurred his father's hatred and the enmity aroused impietas in his resentful son, finally leading to parricidium. So, a son's duty of pietas erga parentes is tied up with his father's natural responsibilities of paterna pietas ${ }^{8}$, for example to give birth, to bring up, to educate and punish, and to pass on a fortune. This filial piety is, therefore, a dutiful virtue

7 Ahn (2009) 124.

8 Cf. animus patrius in liberos in $\S 46$. And also in $\S \S 43,53$ it is suggested indirectly what the father's role and responsibility is. 
derived from ius/iustitia as recognized among human beings; ${ }^{9}$ according to Cicero, ${ }^{10}$ not only is it derived from nature, but it also implies a socially extended range of application.

A part of Cicero's refutation ex causa against Erucius ( $\$ \S 40-54)$ is especially focused on arguing that the motives for the murder which the accuser tried to prove are groundless, or rather that some more strong causes are required, because no one with common sense would dare to commit such an unnatural crime. According to Cicero, a relatively light neglect of pietas is a more frequent situation than an extreme one, but the point that he tries to make obvious is that if Roscius the son did not have any trivial motive for violating pietas, then a fortiori he should have had no reason for killing his father. So Roscius' life is characterized as rather dutiful, obedient, ordinary, and traditional in Cicero's argument.

On the other hand, in a digression about parricide and its punishment (§§ 61-72), other features of pietas are shown indirectly by Cicero. This phase of the speech looks more impassioned than the others, and the apparent reason why the digression is prolonged is due to the pathetic means of persuasion used. However, this probably happens because Cicero has scarcely used any non-technical evidence except the decree of the decemviri of Ameria ( $\$ 25)$, and this lack of evidence might have driven him to extend the length of the digression. In an attempt to avoid leaving a pedantic impression, he adapts some themes familiar to the audience from tragedy and history. The gist of Cicero's argument is that certain abnormal signs should obviously attend whomever offends pietas, such as madness, violence or fear.

\footnotetext{
$\S 66$ : The poets tell of sons who killed their mothers to avenge their fathers. Although they are said to have killed them in response to the commands and oracles of the immortal gods, you have read how the Furies hound them even so, and never let them rest, because they were unable to fulfil their duty towards their fathers without committing a crime. And that is how it really is, gentlemen. The blood of a father or a mother has great power, it is a great bond, and it possesses great sanctity (magnam religionem). The stain it produces, however small, cannot only never be washed out, but seeps right into the mind, so that the utmost violence and insanity ensue.
}

The Furies, which Cicero interprets in $\S 67$ as a psychological symptom, are unavoidable even by those who would violate pietas on account of divine causes. In other words, when any crime is committed, even from pious motivation, it cannot be considered a pious act in itself. Conflict between pious actions brings about

9 Cf. Partitiones oratoriae 78.

10 Cf. De inventione 2.66.161. 
an impious vice. At least in this moment, Cicero appears not to permit the innocence of a kind of pia impietas. ${ }^{11}$ Moreover, no breach of pietas, however small, ought to be overlooked, Cicero says, since it might give rise to violent insanity. This claim, which Cicero ascribes in $\S 37$ to certain philosophers, makes pietas even more compulsory. A son has a difficult but unavoidable duty towards his father, but violation of this duty can happen easily, and the stain created by a non-pious action is never washed out entirely. Nevertheless, the other important aspect of pietas is that the blood relationship has strong power to sanction or prohibit unnatural impietas. In this context, religio ${ }^{12}$ would seem to be an innate force impelling children to keep their human nature, and as a sanction or prohibition to keep one's pietas intact. Because this religio is similar to a kind of commandment given by di parentes ${ }^{13}$ to human nature, pietas would also seem to involve an inseparable relationship with the gods. Therefore, pietas erga parentes should be built on religio, which is pietas erga deos. But in a quite different way, Cicero tries to distinguish it clearly from religio in his early works and rhetorical treatises. ${ }^{14}$

Cicero seems to distinguish pietas from religio by definition, at least theoretically. On the one hand, filial piety, in the narrower sense of pietas, expands its denotation and encompasses a broader range - one's own relatives, citizens, country. This extension of meaning is comparable to the anthropological progression of human society. ${ }^{15}$ A man who had been simply a son of his family became a son of an extended family, then a son of a country. Thus, Cicero's definition of pietas reflects the diachronic extension of meaning from erga parentes to erga patriam. At the same time, the meaning seems to be related to the development of the concept of humanitas. ${ }^{16}$ Although the question to what extent the particularity of Roman society had influenced the idea of pietas, or how great the influence of Hellenistic philosophy was on it, is difficult to answer, at least by the 2nd century BCE this extended idea of pietas might have been

11 Cf. Hinard (2006) n. 4 on $\S 66$.

12 The $O L D$ suggests this religio as an example of the subsection 7a: "a quality (attached to a person, place, object, action, etc.) evoking awe or reverence, sanctity". But it seems also reasonable to adapt 1a, which Dyck (2010) and Berry (2000) preferred: "a supernatural feeling of constraint, usu. having the force of a prohibition or impediment".

13 Cf. Dyck (2010) on $\S 37$.

14 For example, Partitiones oratoriae, 78; De inventione, II.161.

15 In contrast, impietas is a characteristic of the Iron Age, according to Ovid (cf. Metamorphoses 1.148-149: filius ante diem patrios inquirit in annos; / victa iacet pietas ...).

16 Wagenvoort (1980) 3-6. 
well-established. And the idea of pietas as a kind of civic virtue is already shown in a famous verse of Lucilius.

commoda praeterea patriae sibi prima putare

deinde parentum, tertia iam postremaque nostra.

(Lucilius: Marx vv.1337-1338)

But pietas in the forum, as seen above, was neither restricted to the social domain, nor was its religious meaning yet excluded. Actually in Cicero's later works, pietas often means piety towards the gods and is synonymous with religio. $^{17}$

Although the differences in the genre and topics of each work should be taken into account, it is still important that Cicero consistently correlates the idea of pietas with iustitia or aequitas. Of course, the change of terminology from earlier usage to that denoting pietas erga deos can be interpreted as the result of Cicero's retreat to philosophy, either because of his weakened political status or because of his private grief following his daughter's death. ${ }^{18}$ Likewise, in the late Roman republic and the early principate, the concept of pietas is adjusted to this current in the literary works of, for example, Virgil and Livy. Moreover, especially Augustus, who always tried to position himself in the guise of res publica restituta, could conceive of pietas as respect and duty for fathers generally. He still permitted the established republican government, the council of the patres and seniores, to continue by denying any privilege beyond what was allowed by tradition. He became a pious son of parentes and patria by having saved the Roman people from the danger of civil disorder. At the same time, he became an example of the most pious son of a god by avenging his father's murder and by deifying him. Thus, Augustus' policy seems to have merged the dual aspect of pietas/religio into one. This would be the starting point of imperial pietas, ${ }^{19}$ which, in the near future, would come into conflict with Christian pietas, understood as the devotion to only one god.

So, to sum up, pietas is born out of condition of dependency imposed on sons by nature. It is also a virtue which Romans have a duty to maintain towards their parents, especially towards the pater familias, arising from the condition of a patriarchal society. The blood relationship and the socially defined role impose obligations on fathers and sons. In this way, pietas would appear to be a typical

17 For example, De natura deorum 1.116, 2.153; De finibus bonorum et malorum 5.65; Topica 90. 18 Wagenvoort (1980) 8-10.

19 Cf. Ovid, Metamorphoses 1.200-205: ... sic, cum manus impia saevit / ... / nec tibi grata minus pietas, Auguste, tuorum est / quam fuit illa Iovi. 
norm of patriarchal society. On the other hand, the undifferentiated feature of pietas and religio, as seen in the case of pro Sexto Roscio, arguably received an extension of meaning by which later Roman emperors shed light on the aspect of imperial hierarchy of pietas. Pietas between son and father turned into pietas between human son and divine father. Moreover, the deified emperors were to be deferred to both as fathers and as gods. Although Cicero sometimes tried to distinguish the concept of pietas from religio, pietas maintained a latent ambiguity of meaning, capable of ranging from the necessary human nature given by divine origin to the dutiful virtue towards one's parents and to the gods. And with the change of the object or range of application of pietas, the social roles of a man with pietas will have altered gradually, as a son, a citizen, a subject, until the meaning of piety came to mean being faithful before God in Western civilization.

\section{Translating pietas into xiao (孝)}

Pietas, as one of the primary concepts of the Western world, is ostensibly familiar to East Asians, or at least to those who are accustomed to Confucian tradition. Because, as we have seen, the narrower sense of pietas, namely filial piety, is similar to xiao (孝), which traditional Confucianism has always emphasized. It still remains valid in some sense today, even though modernity has changed so many things in the daily life of East Asians. Especially in the language of each nation, as a kind of common cultural property, Chinese characters (漢子) appear to maintain the idea of Confucianism. By reviewing each translation a part of pro Sexto Roscio, discussed above, the way(s) of understanding Cicero's idea of pietas in East Asia may provide a clue to understanding and drawing comparisons between two different civilizations.

First of all, the word pietas, which appears prominently in $\S 37$ (voltu saepe laeditur pietas) of pro Sexto Roscio, has very similar translations in East Asian versions:

종종 표정 하나만으로도 불효(不孝)가 되는 마당에

Just a look often causes filial impiety: Kim et al. (2015)

百恶不孝为先

Filial impiety becomes the first of a hundred evils: Wang (2008)

親に対する孝心は,しばしば子が恋な目つきをするだけで台無しになる

The filial heart towards parents is often ruined by the son with just a lovely glance: Takenaka (2001) 
In some modern Western translations, this pietas is translated into similar expressions, "filial duty" (Berry 2000) or "piété filiale" (Hinard 2006). Because the word-for-word translation 'piety' or 'piété' might produce misunderstanding of its meaning, the translators seem to choose expressions carefully. Likewise, the non-classical term pietas causes some confusion with a religious meaning, especially regarding Christian piety. The latter usually receives the corresponding translation 虔敬 (qianjing) ${ }^{20}$ or 敬 (jing), which means reverence or deference toward a superior being. On the other hand, as seen above, pietas as filial piety enjoys a similar translation 孝 (xiao) in every translation given. Among these, however, particularly noticeable is Wang's translation, which seems to be a contrary proposition to the well-known idiom "Filial piety becomes the first of a hundred goods” (百善孝为先), the significance of which will be discussed later.

Another example comes from $\S 66$ (quod ne pii quidem sine scelere esse potuerunt):

그들은 범죄를 저지르지 않고서는 부친에게 효도(孝道)를 다할 수 없었기에

since they could not to fulfil the duty of filial piety towards their fathers: Kim et al. (2015)

因为他们不犯罪就无法完城他们要对父亲承担的义务

because unless committing a crime, they could not discharge the duty towards their fathers: Wang (2008)

彼らが罪を犯すことなしには,子とてしの義務を果たすせなかったからだ

without committing a crime, they could not fulfil their duty as sons; Takenaka (2001)

The translations in the Chinese and Japanese versions are similar to Berry's consistent choice of word, "duty". ${ }^{21}$ On the other hand, xiao still occupies a part of the word, which also incorporates dao (道) as a component of the Korean translation. Although it is necessary to examine every nuance of expression in each nation's language, it appears that the idea of pius/pietas in pro Sexto Roscio is understood as the son's duty towards his father, and the concept of xiao also seems to imply this nuance. In other words, xiao incorporates yi (righteousness, 義/义) and thus duty (yiwu, 義務/义务) follows after it.

And next, in $\S 69$, quod in impios singulare supplicium invenerunt has translations as follows:

특히 패륜자(悖倫者)들에게 유례없이 가혹한 처벌을 고안해 낸 사실에서 especially from the fact that they devised an unparalleled harsh punishment for the filialimmoral: Kim et al. (2015)

20 By a changing the order of the characters, 敬虔 is usually the standard orthography in Korea and Japan.

21 By contrast, Hinard (2006) maintains the expression "piété filiale". 
为惩罚不义之人, 他们发明了非常奇怪的惩罚办法

for the punishment of undutiful people they devised a very monstrous means of punishment: Wang (2008)

神をも恐れぬ者たち対して独特な罰を案出したことで

By that means they devised a unique punishment for those who are not afraid of God: Takenaka (2001)

Berry translated the phrase in impios as "for sons who violated their filial duty". His choice of words appears to avoid any unnecessary misunderstanding that 'piety' would otherwise bring about in the modern reader's mind. This tendency is also observed in the Chinese translation, but there because the translator referred to the LCL text in which the English translation reads "undutiful" for impios in $\S 69$, as is also the case with 'duty' for pii in $\S 66$. Of course, we might say that $y i$ (義) and xiao (孝) share an inseparable relation, as do pietas and iustitia. On the other hand, it seems a little odd that the Japanese translator reads the meaning of impii as 'those who are not afraid of god'. With regard to this, since as we saw that Cicero also seems to incorporate religio or pietas given by the gods into the idea of filial piety, impii might not be entirely off base. But since, in the text following $\S \S 71-72$, the punishment to which Cicero is referring is the so-called poena cullei, a more exact meaning of impios might be "those who have committed parricide". ${ }^{22}$ On this point, "the filial-immoral" ${ }^{23}$ in the Korean translation seems stronger than other renderings, but it appears to reflect in context the enormity of the crime. If so, such an evaluation of the characteristics of parricide is similar to that discussed above, which Cicero also tried to emphasize. In fact, a violator who breached the precepts of xiao would have been punished with severe penalties in a traditional Confucian society. Such things are also recorded in the Xiaojing (孝經. The Classic of Filial Piety). ${ }^{24}$

The Xiaojing, which deals with filial piety in principle and in concrete precepts, has been read by thousands in East Asia since ancient times when Confucianism became established as a leading ideology of governance, culture, and education. The words above were translated into Chinese characters, which mostly came from this traditional background and are still used in ordinary

22 Translating into "pour les impies", Hinard (2006) points out the difficulty of translating the word impii into French. But he comments that the word signals those who violated the sacred value of Roman family, namely pietas: Hinard (2006) n.2 on $\S 69$.

23 패륜 (悖倫) in Korean means a state of morally deprived human who is usually treated as a lesser being than an animal and excluded from society, just as the Latin homo sacer. In chapter 15 of the Xiaojing, bei (悖) means 'to violate' or 'to pervert'.

24 Xiaojing, ch. 11 has the title "The Five Punishments". It emphasizes that there is no graver crime than buxiao (不孝), namely “the violation of xiao" or impietas. 
life these days, although some ideas of traditional Confucianism are regarded as old-fashioned and sometimes even obsolete. But xiao still remains in the language and in the mentality of East Asians in their different ways of thinking, according to their own cultural heritages. To examine and compare such subtle differences is beyond the scope of this paper. Nevertheless, if xiao represents the common way of translating and understanding Western ideas such as pietas, and if this correspondence is meaningful, then the following preliminary account of the Xiaojing might justify more specific studies to broaden and deepen understanding between East and West by providing new perspectives from one to another.

\section{Reading xiao and translating it into pietas}

The Xiaojing is a dialogue between Confucius (551-479 BCE) and his disciple Zeng Shen (曾參, 505-436 BCE), also known as Master Zeng or Zengzi (曾子), who was famous for his xiao. This work seems to have been written by the Confucian followers of Master Zeng and established as a complete text in the later Warring States period between the 4 th and 3rd centuries BCE. ${ }^{25}$ It consists of 18 short chapters and the volume containing the modern English translation together with the original Chinese text is about 10 pages long. ${ }^{26}$ In the first chapter, Confucius teaches the importance of xiao as both the fundamental principle of ren (humaneness, 仁) and the source of jiao (education, 呚). Then, through a question and answer with Master Zeng, he unfolds the concrete precepts of xiao, which should be observed by each rank of the Confucian imperial hierarchy, from the emperor to the common people. In short, the Xiaojing explicates Confucian social-role ethics on the basis of xiao, or filial piety. ${ }^{27}$

According to Confucius, the emperor should love ( $a$ i, 愛) and respect (jing, 敬) his own parents, whereby the exemplary xiao of the son of Heaven (天子) is then able to educate the common people (ch. 2). This duty of love and respect (愛敬) towards one's parents will also be emphasized at the end of the Xiaojing, which deals with mourning for deceased parents.

When parents are alive they are served with love and respect; when they are deceased they are served with grief and sorrow. This is the basic duty to be discharged by the living, the

25 Cf. Ames/Rosemont (2009) 18-19.

26 So in the edition of Ames/Rosemont (2009)

27 'Filial piety' has been conventionally used as the translation of xiao. 
fulfilling of the appropriate obligations (yi, 義) between the living and the dead, and the consummation of filial service which children owe their parents. ${ }^{28}$

On the one hand, the duty of xiao is justified as both a heavenly principle and as righteousness ( $y i$, 義) on earth (ch. 7), and the relationship between father and son, which is given by nature, becomes by analogy the dutiful righteousness exercised between sovereign and subject (ch. 9). Thus, xiao is the proper way (dao, 道) given by nature to children when they are born into the world. So, Confucian tradition from ancient times has taught followers to preserve one's own person unharmed, even one's hair and skin, which are given by parents along with life. This idea derives from the discipline of the Xiaojing, in which it is suggested as the beginning of xiao (ch. 1). In this way, the Confucian xiao is based on the blood relationship between children and parents, comparable to the notion of filial piety discussed above. So pietas erga parentes imposes on children a necessary and basic duty in the same way that Confucian xiao requires unconditional love and respect for parents. In other words, xiao and pietas both arise from the condition of children's natural reliance upon their source of life, namely their parents. Following birth, children are at first dependent on their parents. From this relation of dependency, dutiful virtues such as love, respect, and obedience are expected and demanded from children while they are under the protection and upbringing of parents. In this way, xiao and pietas are both based on a kind of naturalism, where nature itself is a source and a cause of human conduct. And this retrospective to origins proceeds to to a superior or fundamental causes, for example, ancestors, gods, or heaven (天) itself. There can be a way in which xiao and pietas both virtually imply religio in pietas, 敬 in 孝.

While initially based on this naturalistic justification, the duties of xiao or pietas appear to develop in social ways. As mentioned above, pietas in the narrower sense and patria potestas have a form of mutuality. In Roman society a kind of dependence could not be dissolved until the son himself became an independent pater familias, and a father had responsibilities for his son, for example, to bring him up, educate him, get him married. And given the well-known role that fathers usually played in the education of their sons in Cicero's times, Roman pietas from the fathers, namely paterna pietas, should have been a source of education in the same way that the educational importance of xiao is emphasized in the Xiaojing. In fact, pietas or xiao is an intergenerational duty which has to be passed down by extension to one's son(s), vassal(s) or subject(s). Thus, both in ancient Rome and in traditional Confucian societies,

28 Xiaojing ch. 18. The translation of cited passage is from Ames/Rosemont (2009). 
the elders or seniors, the high rankers of order, are deferred to and respected by the younger and/or the lower class. On this point, xiao or pietas functioned as central ideas which sanctified a social system based on a patriarchal ideology.

The Confucian governmental ideal in the Xiaojing expects even the ruler-emperor to assume xiao in his ruling policy, just as it occurs in the family (ch. 8). This metaphorical expression of family appears to signify the role of the emperor as a son of parents, the son of Heaven, and the father of the people and the state. The dual identity of both son and father implies some overlapping or ambivalence, but it is similar to the symbolical representations of ruling roles which were given to the later Roman rulers of the imperial court. The state, as an extended family, is prescribed in the Xiaojing to be governed in accordance with the principle of xiao. Although xiao itself is not the absolute goal of such an ideal Confucian society, it is suggested as the proper rule and the principal code of human conduct that guarantees that if all the members of society attend to their duties in compliance with xiao, such a state could be seen as peaceful (he, 和) (ch. 8). On this point, xiao is the basis from which the other important principles of Confucian social ethics develop, for example ren (仁), yi (義), li (禮) and $z h i$ (智). ${ }^{29}$

Furthermore, to fulfil one's pietas of filial duty, or xiao, is something assigned to men whose aims are personal aggrandizement in androcentric societies. On one side of the social ethics of xiao, there are the duties regarding obedience to the elder or ruling class and the fulfillment of one's roles given by the order of hierarchy. On the other hand, it is necessary for a man to take care of the younger generation and the lower class and to lead them such that he would function as a father and an authority in an extended family, a broader society, and a state. Likewise, in this way, Roman humanitas might be said to embrace pietas as a virtue of manliness by which a vir bonus could be characterized by his actions towards his parents, his citizens, and his country. Thus, such social ethics arising from filial piety would provide an efficient program to socialize and accommodate someone into the established order. But the educational function of filial piety in the family, which seems to be applicable to more extended social relations, is restricted to maintaining and reproducing the order of patri-

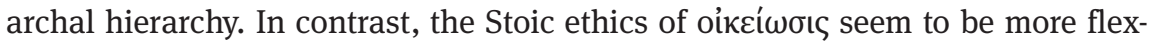
ible, implying rather open cosmopolitan role ethics. Thus it might have had some influence on the formation of Roman humanitas and the development of the idea of pietas.

29 Ames/Rosemont (2009) 22-23. See also, Analects (論語, Lunyu) I.2: “孝悌也者, 其爲仁之本 與!”. (Filial and fraternal piety, they are the foundation of the humaneness (ren, 仁)!) 
The Confucian xiao was transformed into a systematic ethics of conduct at a relatively early period because Confucianism was adopted as the philosophy and ideology of governance of the empire. The imperial constitution, which was supported and justified by Confucianism, began to demand that its administrators be well-matched to its ideal. Thus almost all of the state's offices were managed by Confucian scholar-officials, who became the main ruling elite of the empire. The Xiaojing was the main source from which such a political elite could learn xiao at a young age. Xiao was a basic duty to learn from childhood, and it was the first step to following the rules laid down by society. In this regard, xiao, filial piety, like Roman pietas, is not only a human duty given by nature, but also a duty imposed by the social system. Also, it is well illustrated as the so-called zhengming (正名, the rectification of names) in the Analects 12.11:

Duke Jing of Qi asked Confucius about good governance. Confucius answered: "The ruler becomes ruler, the minister minister, the father father, and the son son". ${ }^{30}$

Thus the violation of pietas, or buxiao (不孝), may be considered disobedience and disloyalty to the conservative order of society. ${ }^{31}$ With this point in mind, an undertone may be understood in the word choice of the translators for Cicero's expressions relating to pietas. It is difficult to answer which translation is most acceptable. And this difficulty is not only for East Asian translations and studies of Cicero. For example, a new recent translation of the Xiaojing has made a fresh attempt, choosing the phrase "family reverence" instead of the conventional "filial piety" for xiao. The translators suggest some reasons for this, but it is doubtful whether their choice will be welcome. ${ }^{32}$ Another interesting example is the Latin translation of the Xiaojing from the 18th century. Perhaps François Noël wanted to avoid the misunderstanding that could arise from using the word pietas for xiao; he translated the end of the Xiaojing which is cited above, like this:

30 “齊景公 問政於孔子. 孔子對曰: 君君臣臣父父子子”.

31 But it is interesting that the possibility of disobedience is partly guaranteed for the sons in the Xiaojing, ch. 15. Jian (諫) is similar to libertas or $\pi \alpha \rho p \eta \sigma^{\prime} \alpha$, and it can be called pia impietas in some sense. On the other hand, it is worth considering the famous example of the Confucian dilemma between pietas and iustitia (Analects, XIII.18), which has often been compared with the case of Plato's Euthyphro. In short, the issue in both cases is whether the son should accuse the father of the criminal offence.

32 The emphasis on the role ethics of Confucianism seems to make them consider xiao 'in' the family. For their justification of this provocative attempt, see Ames/Rosemont (2009) 1-3, 87-90. 
denique si vivis Parentibus amore et honore, mortuis luctu et maerore inserviatur, videtur viventis filii munus omnino adimpletum esse, mortisque ac vitae aequitas exacte servata. atque is est filialis erga Parentes observantiae ultimus finis.

Although it may not be claimed that the equivalence between xiao and pietas is simply demonstrated and that they are interchangeable terms, nevertheless a detailed comparison of the two will provide more helpful guidance for understanding, translating, and communicating with new perspectives. In order to achieve this, more comparative studies will be needed in the future. At first glance there may appear to be no direct equivalence, yet some comparisons may provide the possibility of studying further the relationship between the two concepts. Incidentally, the Confucian ideal portrait of the pious son is described virtually in the character xiao itself. 孝 is the composite character of lao (老, senex) and $z i$ (子, filius). And the shape of the more complex 孝 ostensibly shows the image of a son holding onto the shoulder his old father. This image recalls the famous sculpture of G. L. Bernini, “Aeneas, Anchises, and Ascanius” (1618-19), which holds forth a model of the pious man of Rome. Someone standing before the statue might reasonably think of Aeneas as a hero of Confucian xiao. 
